\title{
NEWLY RECORDED LEPISTA SORDIDA (SCHUMACH.) SINGER (AGARICALES: TRICHOLOMATACEAE) FOR INDONESIA
}

\author{
Atik Retnowati \\ Herbarium Bogoriense, Botany Division, Research Center for Biology-LIPI Cibinong Science Center \\ Jln. Raya Jakarta-Bogor Km. 46, Cibinong 16911, Bogor, Indonesia \\ Email: marasjamur@gmail.com
}

Atik Retnowati. 2019. Rekaman Baru Lepista sordida (Schumach.) Singer (Agaricales: Tricholomataceae) untuk Indonesia. Floribunda 6(3): 81-84. — Lepista sordida (Schumach.) Singer dilaporkan untuk pertama kalinya dari Indonesia. Deskripsi dan ilustrasi jenis disajikan.

Kata kunci: Agaricales, Jawa, rekaman baru.

Atik Retnowati. 2019. Newly Recorded Lepista sordida (Schumach.) Singer (Agaricales: Tricholomataceae) for Indonesia. Floribunda 6(3): 81-84. - Lepista sordida (Schumach.) Singer is firstly reported from Indonesia. Description and illustration of the species are presented.

Keywords: Agaricales, Java, new record.

Lepista has been traditionally placed in the Tricholomataceae tribe Tricholomateae (Singer 1986). Lepista consists of approximately 50 species in the world (Kirk et al. 2008), but molecular phylogenetic analyses suggested that the genus is not monophyletic (Alvarado et al. 2015). The species within the genus have medium to large fruiting body, pinkish-buff spore deposit, convex to plane or becoming infundibuliform pileus, sinuate to decurrent attachment of lamellae, and white or co-loured pileus (Largent \& Baroni 1988).

They mostly grow on the ground compost and in the woods gardens, in lawns, or parks (Largent \& Baroni 1988). The genus Lepista was introduced by W.G. Smith in 1870 where he elevated the tribe Lepista of the genus Paxillus of Fries 1838 (Bigelow \& Smith 1969). The genus contains some best known edible species, and one of them is L. sordida. Recent study has reported the successful fruiting body production of wild $L$. sordida, and therefore the species has a high potential for commercial production (Thongbai et al. 2017) for its nutritive and medicinal value. As a medicinal mushroom, L. sordida has been shown to have anti-cancer, anti-microbial, and anti-tumor properties in vivo and in vitro from both submerged cultures and fruiting bodies (Thongbai et al. 2017). It produces two diterpenes that induce differentiation in human leukemic cell. The species also produce lipid material that embedded at the basidiospores which plays an important role in the vital metabolic activity (Graf et al. 2008).

L. sordida is a cosmopolitan species and has been reported from East Africa (Pegler 1977),
Srilanka (Pegler 1986), Switzerland (Breitenbach \& Kränzlin 1991), Western North America (Davis et al. 2012), Eastern North Africa (El-Fallal et al. 2017) and Thailand (Thongbai et al. 2017).

Thus far there is no report of the species from Indonesia, but recently a colony was spotted in Java. This new finding is presented.

\section{MATERIALS AND METHODS}

Macro- and micromorphological characters are described and illustrated based on fresh and dried fungal specimens collected from Java. Microscopic observation was made on material mounted in $3 \% \mathrm{KOH}$. Colour notation was determined using Kornerup \& Wanscher (1978) (in the descriptions these appear as, for example, 18A5-18A4). Ornamentation of basidiospores was obser-ved by JEOL JSM-5310 LV Scanning Microscope. Specimen examined is deposited in Herbarium Bo-goriense (BO), Indonesia.

All line drawings of the micro-characters were made with the aid of a camera lucida attached to a compound microscope using $40 \times$ or $100 \times$ (oil immersion) objectives. Spore range was obtained by measuring 25 mature basidiospores. Basidiospore statistics include: the arithmetic mean of the spore length by spore width $( \pm$ standard deviation) for $\mathrm{n}$ spores measured in a single specimen $\left(\mathrm{x}_{\mathrm{m}}\right)$; the range of spore means $\left(\mathrm{x}_{\mathrm{mr}}\right)$, and the mean of spore means $( \pm$ SD) when more than one specimen is available $\left(\mathrm{x}_{\mathrm{mm}}\right)$; the quotient of basidiospore length and basidiospore width in any one basidiospore, indicated as a range of variation 
in $\mathrm{n}$ basidiospores measured $(\mathrm{Q})$; the mean of $\mathrm{Q}$ values in a single specimen $\left(\mathrm{Q}_{\mathrm{m}}\right)$; the range of $\mathrm{Q}_{\mathrm{m}}$ values where more than one specimen is available $\left(\mathrm{Q}_{\mathrm{mr}}\right)$; and the mean of $\mathrm{Q}_{\mathrm{m}}$-values where more than one specimen is available $\left(\mathrm{Q}_{\mathrm{mm}}\right)$ (Retnowati 2018).

\section{TAXONOMIC DESCRIPTION}

Lepista sordida (Schumach.) Singer in Lilloa 22: 193 (1951). Figures 1-2.

Agaricus sordidus Schumach., Enum. pl. (Kjbenhavn) 2: 341 (1803); Tricholoma sordidum (Schumach.) P. Kumm., Führ. Pilzk. (Zerbst): 134 (1871); Gyrophila sordida (Schumach.) Quél., Enchir. fung. (Paris): 18 (1886); Rhodopaxillus sordidus (Schumach.) Maire, Annals Mycol. 11(4): 338 (1913); Melanoleuca sordida (Schumach.) Murrill, Mycologia 6(1): 3 (1914). - Holotype: untraced.
L. sordida can be diagnosed by the following features: medium, convex to broadly convex with violet light pileus; crowded lamellae with 4-5 series of lamellulae; relatively small basidiospores, cystidia absent, and it is known as edible mushroom.

Pileus $1.5-10 \mathrm{~cm}$ in diam, convex to broadly convex, infundibuliform with depressed central when mature, strongly hygrophanous with light violet (18A5-A8A4) at the margin, drying violet white (18A2); margin inrolled in young specimens, becoming straight to slightly wavy with age, striate when moist; surface dull, dry, glabrous, light violet (18A5-18A4). Context thick, pale purple. Lamellae adnate to adnexed, or subdecurrent, crowded with 4-5 series of lamellulae, broad, thick, margin wavy, narrow, non-marginate, light violet (18A5-A8A4). Stipe 4.5-9.5 × 0.3-1.5 cm, central, cylindrical, solid, glabrous, concolorous with pileus. Odour and taste indistinct.

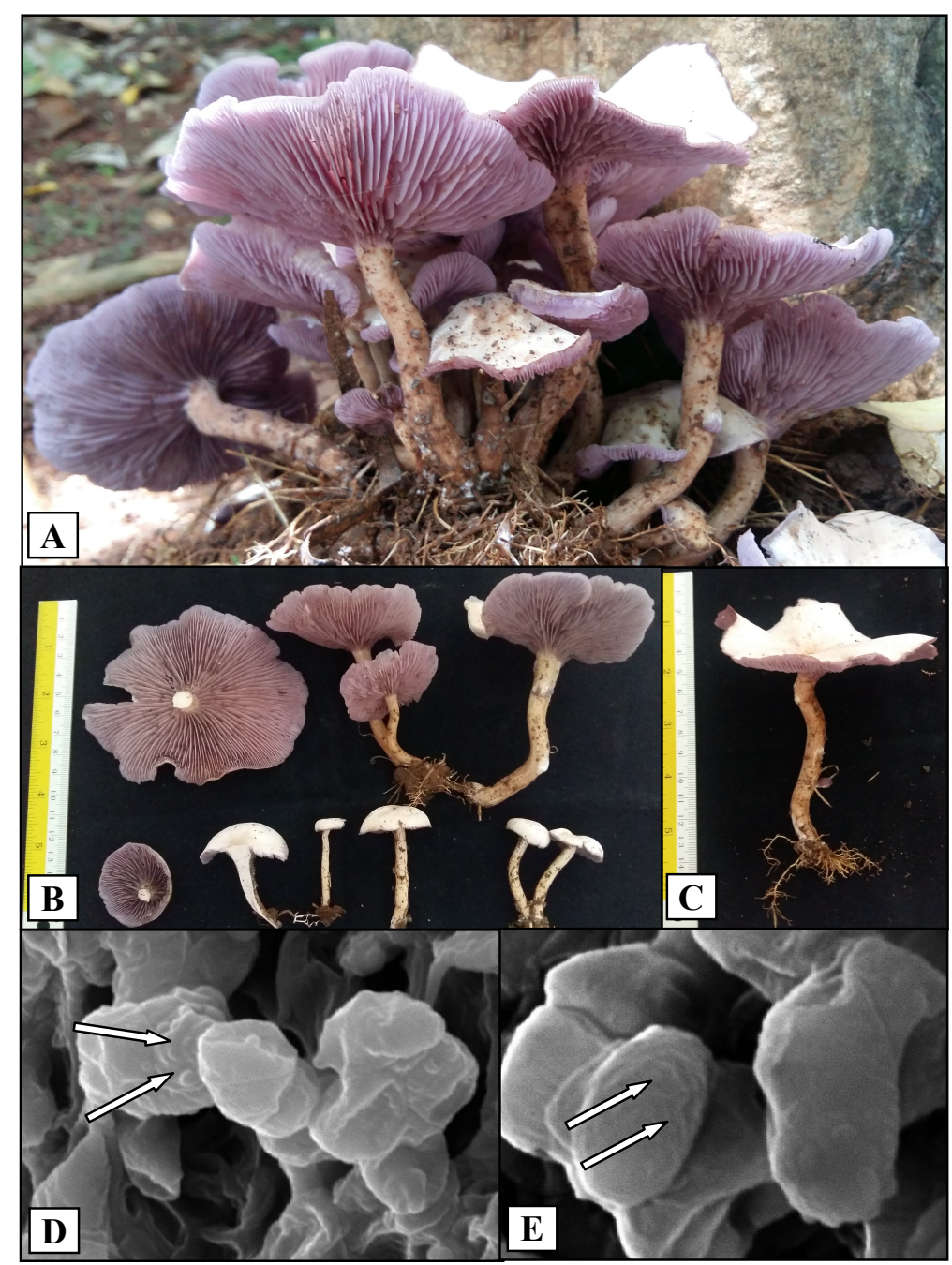

Figure 1. L. sordida (Schumach.) Singer. A. Caespitose habit; B. and C. Morphological characters of basidiomes; D. and E. Basidiospore surface with ornament through SEM. Photos A, B and C by A. Retnowati. 


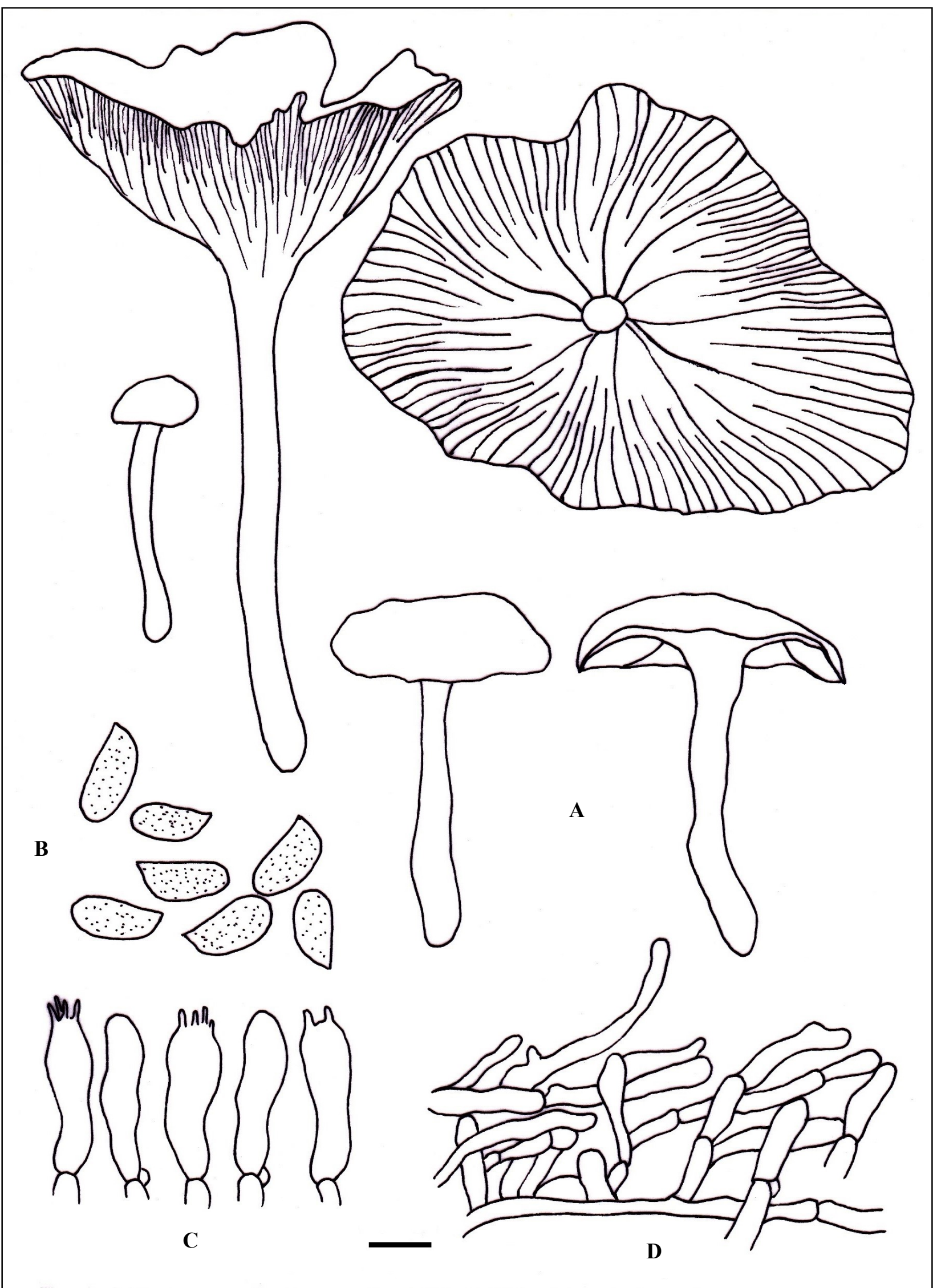

Figure 2. L. sordida (Schumach.) Singer. A. Basidiomes. B. Basidiospores. C. Basidia and basidioles. D. Pileipellis. Scale bar: B $=5 \mu \mathrm{m} ; \mathrm{C}-\mathrm{D}=10 \mu \mathrm{m}$. Drawn by A. Retnowati from A. Retnowati 1234. 
Basidiospores 5.6-8.0 × (2.4-) 3.2-4.0 $\mu \mathrm{m}$ $\left(\mathrm{x}_{\mathrm{m}}=6.59 \pm 0.70 \times 3.26 \pm 0.32, \mathrm{Q}=1.60-2.50, \mathrm{Q}_{\mathrm{m}}\right.$ $=2.03 \pm 0.22, \mathrm{n}=25$ spores per 1 specimen), ellipsoid, verrucose, hyaline, inamyloid, thinwalled. Basidia 24-32 ×6.4 $\mu \mathrm{m}$, clavate, 4-spored. Basidioles clavate. Pleurocystidia absent. Cheilocystidia absent. Pileipellis cutis, hyphae 2.4 $-4 \mu \mathrm{m}$, thin-walled, smooth, hyaline, inamyloid. Pileus trama interwoven; hyphae 4.0-5.6 $\mu \mathrm{m}$, thinwalled, inamyloid. Stipe tissue monomitic; hyphae 3.2-12.0 $\mu \mathrm{m}$ diam, cylindrical, parallel, thinwalled, smooth. Stipe vesture absent. Clamp connection present.

Distribution. Indonesia (Java), Srilanka, Thailand, Africa (East and Eastern North Africa), America (Western North America), and Switzerland.

Specimen examined. Indonesia, West Java, Cibinong, caespitose on soil under the Anona reticulata (Annonaceae) at the backyard of Herbarium Bogoriense, 5 March 2018, Retnowati 1234 (BO).

\section{ACKNOWLEDGEMENT}

The author greatly thanks to Deden Girmansyah who first spotted the material and identified the plant species where the mushroom found.

\section{REFERENCES}

Alvarado P, Moreno G, Vizzini A, Consiglio G, Manjón JL \& Setti L. 2015. Atractosporocybe, Leucocybe and Rhizocybe: three new clitocyboid genera in the Tricholomatoid clade (Agaricales) with notes on Clitocybe and Lepista. Mycologia, 107(1): 123-136, DOI: 10.3852/13-369.

Bigelow HE \& Smith AH. 1969. The status of Lepista-A new section of Clitocybe. Brittonia 21(2): 144-177.

Breitenbach J \& Kränzlin F. 1991. Fungi of Switzerland. Vol. 3: Boletes and agarics $1^{\text {st }}$ part. Verlag Mykologia: Luzern, Switzerland. pp. 214-216.
Davis RM, Sommer R \& Menge JA. 2012. Field Guide to Mushrooms of Western North America. University of California Press, Berkeley, Los Angeles, California. 472 p.

El-Fallal AA, El-Sayed AKA \& El-Gharabawy HM. 2017. First record of Lepista sordida (Schumach.) Singer in Eastern North Africa. Egypt. J. Bot. 57 (The 7th Inter. Conf. Plant \& Microbial Biotech. \& their Role in the Development of the Society): 111-118.

Graf LV, Schadeck RJG, Donatti L \& Buchi DF. 2008. Morphological and cytochemical characterization of spores and gills of Lepista sordida (Fungi: Basidiomycota). Brazilian Journal of Microbiology 39: 599-601.

Kirk PM, Cannon PF, Minter DW \& Stalpers JA. 2008. Ainsworth and Bisby's Dictionary of the Fungi. 10th ed. Wallingford, UK: CABI Publishing. 374 p.

Kornerup A \& Wanscher JH. 1978. Methuen Handbook of Colour. 3rd. Ed. Eyre Methuen, London. 252 p.

Largent DL \& Baroni TJ. 1988. How to Identify Mushrooms to Genus IV: Modern Genera. Mad River Press, USA, Eureka., 277 p.

Pegler DN. 1977. A preliminary agarics flora of East Africa. Kew Bull. Add. ser. 6: 1-615.

Pegler DN. 1986. Agarics flora of Sri Lanka. Kew Bull. Add. Ser. 12: 144-172.

Retnowati A. 2018. The species of Marasmiellus (Agaricales: Omphalotaceae) from Java and Bali. Gardens' Bulletin Singapore 70(1): 191-258.

Singer R. 1986. The Agaricales in Modern Taxonomy. 4th ed. Koenigstein, Germany: Koeltz Scientific Books. 981 p.

Thongbai B, Wittstein K, Richter C, Miller SL, Hyde KD, Thongklang N, Klomklung N, Chukeatirote E \& Stadler M. 2017. Successful cultivation of a valuable wild strain of Lepista sordida from Thailand. Mycological Progress 16 (4): 311-323. 